\section{Commentary: If it looks like a duct and it cracks like a duct, it most likely is a duct}

\author{
Osman O. Al-Radi, MBBCh, MSc, FRCSC
}

In this issue of the Journal, Divekar and Sebastian ${ }^{1}$ describe a technique of arch repair in a rare variant of coarctation of the aorta with persistent fifth aortic arch with both the fourth and fifth aortic arches on the same side of the trachea. They found it useful to incorporate the tissue of the persistent fifth aortic arch in the repair to minimize the size of the needed patch material. They claim that even though the fifth aortic arch was prostaglandin-sensitive in their case, its use was still acceptable because it was "not ductal tissue."

This type of arch repair would not be my first choice, given that it is quite simple to do either extended endto-end or arch advancement in this setting, which eliminates the use of any foreign material and has welldocumented excellent outcomes. ${ }^{2,3}$ Nonetheless, the method described by Divekar and Sebastian is an acceptable technique. I do disagree with the authors' suggestion that incorporating prostaglandin-sensitive tissue that does not look like duct is acceptable. Their claim has 2 logical flows. First, the fact that the infant responded to prostaglandin with improved lower limb pulses does not mean that the entire persistent fifth aortic arch is prostaglandin-sensitive. It may be that ductal tissue extends in to the periductal aortic wall in the fourth or fifth arch or even the descending aorta. Second, without histological testing, there is no proof that the retained issue is or is not ductal tissue and/or prostaglandin-sensitive. In

\footnotetext{
From the Department of Surgery, Faculty of Medicine and Pediatric Cardiac Center of Excellence, King Abdulaziz University, Jeddah, Saudi Arabia.

Disclosures: The author reported no conflicts of interest.

The Journal policy requires editors and reviewers to disclose conflicts of interest and to decline handling or reviewing manuscripts for which they may have a conflict of interest. The editors and reviewers of this article have no conflicts of interest.

Received for publication Oct 24, 2020; revisions received Oct 24, 2020; accepted for publication Oct 28, 2020; available ahead of print Nov 17, 2020.

Address for reprints: Osman O. Al-Radi, MBBCh, MSc, FRCSC, Department of Surgery, Faculty of Medicine and Pediatric Cardiac Center of Excellence, King Abdulaziz University, Jeddah, Makkah Province 21589, Saudi Arabia (E-mail: oradi@ kau.edu.sa).

JTCVS Techniques 2020;4:247

2666-2507

Copyright (C) 2020 The Authors. Published by Elsevier Inc. on behalf of The American Association for Thoracic Surgery. This is an open access article under the CC BY-NCND license (http://creativecommons.org/licenses/by-nc-nd/4.0/).

https://doi.org/10.1016/j.xjtc.2020.10.043
}

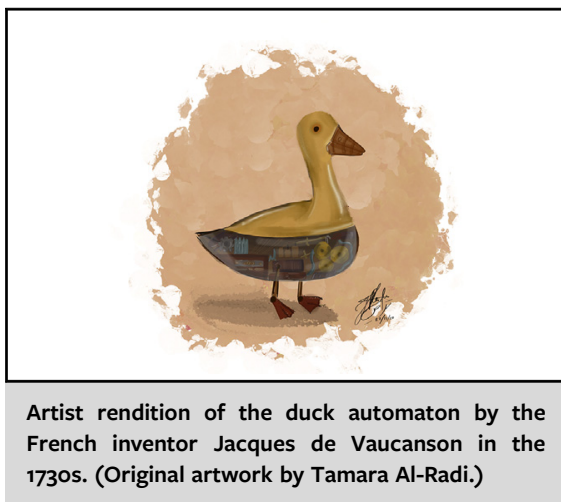

\author{
CENTRAL MESSAGE \\ Resection of all ductal tissue \\ during aortic arch repair is a \\ time-tested principle of congen- \\ ital cardiac surgery. The assump- \\ tion that the persistent fifth \\ aortic arch that does not look \\ like ductal tissue is prostaglandin- \\ sensitive is unfounded.
}

fact, ductal tissue and prostaglandin sensitivity are probably necessarily coexistent properties.

As the authors suggest, it is quite cumbersome to perform histological tests during aortic arch surgery involving complex, time-sensitive perfusion techniques. This may be a case of overthinking a problem. I would stick to the ageold so-called "duck test": if it looks like a duck, walks like a duck, and quacks like a duck, it most likely is a duck! In our case, if it looks like a duct and cracks like a duct (when handled by forceps), it most likely is a duct and should be cut out. Pun intended in this case!

\section{References}

1. Divekar AA, Sebastian VA. Neonatal repair of persistent fifth aortic arch and aortic coarctation. J Thorac Cardiovasc Surg Tech. 2020;4:245-6.

2. De León LE, McKenzie ED. Aortic arch advancement and ascending sliding arch aortoplasty for repair of complex primary and recurrent aortic arch obstruction. Semin Thorac Cardiovasc Surg Pediatr Card Surg Ann. 2017;20:63-6.

3. Dharmapuram AK, Ramadoss N, Verma S, Vejendla G, Ivatury RM. Early outcomes of modification of end-to-side repair of coarctation of aorta with arch hypoplasia in neonates and infants. Ann Pediatr Cardiol. 2018;11:267-74. 